\title{
VARIASI WAKTU EKSTRAKSI DAN JENIS ASAM PADA PROSES PRODUKSI GELATIN TULANG IKAN NILA (Oreochromis niloticus)
}

\author{
Neneng Suliasih, Asep Dedy Sutrisno, Nabella Respatyana \\ Program Studi Teknologi Pangan, Fakultas Teknik, Universitas Pasundan Jl. Dr. Setiabudi No. 193 Bandung 40153, \\ Indonesia
}

Email : nenengsuliasih@unpas.ac.id

\begin{abstract}
The purpose of this research is to find out determine the effect of the most effective extraction time and to determine the effect of the most effective type of acid in the production process of gelatin bone of tilapia fish. This research was using by Split Plot Design (SPD) with 3 times replication, so make 27 experiments were obtained. For main plot is extraction time (4 hours, 5 hours and 6 hours) and subplot is type of acid (4\% chloride acid, 3\% acetic acid and 6\% citrate acid). Response in this research is physical response such as gel gelatin strength, viscosity and rendement total, chemical response such as $\mathrm{pH}$, protein content and ash content and test of bone gelatin of tilapia fish with commercial gelatin. The main research result showed that the extraction time had significant effect on gelatin gel strength, gelatin viscosity, gelatin rendement, acidity degree $(\mathrm{pH})$ of gelatin, gelatin protein content and gelatin ash content. Types of acid had significant effect on gelatin gel strength, gelatin renedement, acidity degree $(\mathrm{pH})$ of gelatin, gelatin protein content and gelatin ash content, and interaction of time of extraction and type of acid had significant effect on gelatin gel strength, gelatin viscosity, gelatin rendement, acidity degree $(\mathrm{pH})$ of gelatin, gelatin protein content and gelatin ash content to the extraction process of bone gelatin of tilapia fish. Based on the comparative test, the characteristics of gelatin of tilapia bone that close to commercial gelatin are a3b2 treatment (6 hours of extraction time, $3 \%$ acetic acid) with the result of gelatin gel strength 132,93 bloom; viscosity 5,83 cP; the amount of rendement 16,94; pH 6,10; protein content 83,62\%; and ash content of $0.64 \%$.
\end{abstract}

Keywords : Gelatin, Tilapia Bone, Gelatin Extraction, Type of Acid, Extraction Time.

\section{Pendahuluan}

Gelatin merupakan protein hasil hidrolisis parsial kolagen tulang dan kulit. Penggunaan gelatin sangat luas khususnya dalam bidang industri, baik industri pangan maupun non pangan. Gelatin memiliki sifat yang khas, yaitu berubah secara reversible dari bentuk sol ke bentuk gel, mengembang dalam air dingin, dapat membentuk film serta mempengaruhi viskositas suatu bahan dan dapat melindungi sistem koloid. Kelarutannya dalam air membuat gelatin diaplikasikan untuk keperluan berbagai industri (Wahyuni, 2003).

Ikan dapat digunakan sebagai bahan baku gelatin. Ikan nila merupakan salah satu jenis ikan air tawar yang dibudidayakan oleh masyarakat Indonesia. Permintaan akan daging fillet nila sangat tinggi. Tercatat ekspor fillet ikan nila dalam bentuk beku Indonesia di pasar Amerika Serikat menduduki peringkat ke dua setelah Cina.(Haris, 2008).

Asam mampu mengubah serat kolagen triple heliks menjadi rantai tunggal, sedangkan larutan perendam basa hanya mampu menghasilkan rantai ganda. Hal ini menyebabkan pada waktu yang sama jumlah kolagen yang dihidrolisis oleh larutan asam lebih banyak daripada larutan basa. Karena itu perendaman dalam larutan basa membutuhkan waktu yang lebih lama untuk menghidrolisis kolagen (Ward dan Courts, 1977).

Pada tahap perendaman dapat dilakukan dengan larutan asam organik seperti asam asetat, sitrat, fumarat, askorbat, malat, suksinat, tartarat, dan asam lainnya yang aman dan tidak menusuk hidung. Sedangkan asam anorganik yang biasa digunakan adalah asam hidroklorat, fosfat, klorida, dan sulfat (Ward dan Courts, 1977).

Gelatin diperoleh dengan cara denaturasi panas dari kolagen (Amiruldin, 2007).

Ekstraksi adalah proses denaturasi untuk mengubah kolagen menjadi gelatin dengan penambahan senyawa pemecah ikatan hidrogen pada suhu kamar atau suhu yang lebih rendah. Ekstraksi juga dapat dilakukan dengan menggunakan air panas, dimana pada proses ini terjadi denaturasi, peningkatan hidrolisis dan kelarutan gelatin. Waktu yang diperlukan untuk ekstraksi adalah $4-8$ jam dengan suhu antara $55-100^{\circ} \mathrm{C}$. Setelah diperoleh ekstrak bersih, dilakukan pengeringan untuk mengurangi kadar air sebanyak $85-90 \%$. Hal ini dapat dilakukan dengan menggunakan evaporator vakum dengan suhu $43-45^{\circ} \mathrm{C}$ dan dilanjutkan dengan menggunakan oven pada suhu antara $30-60^{\circ} \mathrm{C}$ (Hadi, 2005). 


\section{Bahan dan Metode}

Bahan baku yang digunakan adalah tulang ikan nila berumur 4 bulan, 5 bulan dan 6 bulan bagian badan yang diperoleh dari perairan waduk cirata cianjur. Bahan tambahan yang digunakan adalah $\mathrm{HCl} 4 \%$, $\mathrm{CH} 3 \mathrm{COOH} 3 \%$, $\mathrm{C} 6 \mathrm{H} 8 \mathrm{O} 76 \%$, akuades.

Alat yang digunakan untuk proses penelitian ini adalah pisau, baskom, timbangan, panci, termometer, talenan, toples, gelas kimia dan kain blacu.

Penelitian pendahuluan yang dilakukaan bertujuan untuk mengetahui kandungan protein yang ada di dalam tiap tulang ikan nila pada ikan nila yang berumur 4 bulan yang memiliki berat berkisar $150-170 \mathrm{~g}, 5$ bulan yang memiliki berat berkisar $190-210 \mathrm{~g}$ dan 6 bulan yang memiliki berat berkisar $240-260 \mathrm{~g}$ sebelum dilakukan proses ekstraksi gelatin.

Penelitian utama yang dilakukan yaitu proses ekstraksi gelatin dari tulang ikan nila, penelitian ini bertujuan untuk mengetahui interaksi antara waktu ekstraksi dan jenis asam yang digunakan terhadap respon fisik, kimia dan uji banding pada gelatin tulang ikan nila. Sehingga dapat ditentukan sampel terpilih yang memiliki karakteristik seperti gelatin komersial.

\section{Hasil dan Pembahasan}

\subsection{Penelitian Pendahuluan}

Analisis Protein metode Kjedhal yang dilakukan pada tulang ikan yang berumur 4 bulan dengan berat ikan $150-170 \mathrm{~g}, 5$ bulan dengan berat ikan $190-210$ g, serta 6 bulan dengan berat ikan $240-260$ g. Berat tulang ikan sendiri yaitu berkisar $8-10 \%$ dari berat ikan utuh.

\begin{tabular}{|c|c|}
\hline Umur Ikan & Kadar Protein (\%) \\
\hline 4 Bulan & 21,64 \\
\hline 5 Bulan & 22,77 \\
\hline 6 Bulan & 24,12 \\
\hline
\end{tabular}

Pada penelitian pendahuluan ini didapatkan hasil tulang ikan yang memiliki kandungan protein paling tinggi adalah pada tulang ikan yang berumur 6 bulan yaitu $24,12 \%$, sehingga tulang ikan nila yang digunakan pada penelitian utama adalah ikan nila yang berumur 6 bulan.Kandungan protein pada ikan dalam jaringan tubuh dan tulangnya akan meningkat disaat mencapai pada umur yang optimal (Buwano, 2004).

\subsection{Penelitian Utama}

\section{Respon Fisik}

\section{Kekuatan Gel Gelatin}

\begin{tabular}{|c|c|c|c|c|c|c|}
\hline \multirow{2}{*}{$\begin{array}{l}\text { Waktu } \\
\text { Ekstraksi }\end{array}$} & \multicolumn{6}{|c|}{ Jenis Asam } \\
\hline & \multicolumn{2}{|c|}{$\begin{array}{c}\mathrm{b}_{1} \text { (Asam Klorida } \\
4 \% \text { ) }\end{array}$} & \multicolumn{2}{|c|}{$\begin{array}{c}\mathrm{b}_{2} \text { (Asam Asetat } \\
3 \%)\end{array}$} & \multicolumn{2}{|c|}{$\begin{array}{c}\mathrm{b}_{3} \text { (Asam Sitra } \\
6 \%)\end{array}$} \\
\hline \multirow{2}{*}{$a_{1}(4$ jam $)$} & 79,70 & $\mathrm{~A}$ & 71,35 & $\mathrm{~A}$ & 65,20 & $\mathrm{~A}$ \\
\hline & c & & b & & a & \\
\hline \multirow{2}{*}{$a_{2}(5$ jam $)$} & 103,63 & B & 126,55 & B & 90,12 & B \\
\hline & $\mathrm{b}$ & & c & & a & \\
\hline \multirow{2}{*}{$a_{3}(6$ jam $)$} & 110,19 & C & 132,93 & C & 100,22 & $\mathrm{C}$ \\
\hline & b & & c & & a & \\
\hline
\end{tabular}

Keterangan: Huruf besar dibaca vertical dan huruf kecil dibaca horizontal.
Dari tabel diatas dapat dilihat pada perlakuan jenis asam b (Asam Klorida 4\%) semakin lama waktu ekstraksi semakin tinggi kekuatan gel gelatinnya begitupula pada perlakukan jenis asam $\mathrm{b}_{2}$ (Asam Asetat $3 \%$ ) dan $b_{3}$ (Asam Sitrat 6\%). Hal ini disebabkan karena pembentukan gel gelatin terjadi saat pengembangan molekul gelatin pada waktu pemanasan. Panas akan membuka ikatan-ikatan pada molekul gelatin dan cairan yang semula bebas mengalir menjadi terperangkap di dalam struktur tersebut, sehingga terbentuk gel yang kental (Stainsby, 1977).

Dari tabel diatas dapat dilihat pula pada perlakuan waktu ekstraksi $a_{1} \quad$ (4 jam) jenis asam $b_{1}$ (Asam Klorida 4\%) memiliki kekuatan gel gelatin yang paling tinggi, tetapi pada perlakuan $\mathrm{a}_{2}(5$ jam $)$ dan $\mathrm{a}_{3}$ (6 jam) jenis asam $b_{2}$ (Asam Asetat 3\%) yang memiliki kekuatan gel gelatin paling tinggi. Hal ini disebabkan karena konsentrasi asam yang semakin tinggi dan peningkatan waktu ekstraksi menyebabkan terjadinya hidrolisis lanjutan pada kolagen yang sudah terkonversi menjadi gelatin, yang menyebabkan pendeknya rantai asam amino sehingga kekuatan gel menjadi rendah. Menurut Stainsby (1977), kekuatan gel berhubungan dengan panjang rantai asam aminonya. Pembentukan gel gelatin dipengaruhi oleh beberapa faktor antara lain $\mathrm{pH}$. Dari hasil penelitian ini terlihat adanya kecenderungan hubungan antara nilai $\mathrm{pH}$, viskositas dan kekuatan gel. Apabila nilai $\mathrm{pH}$ tinggi maka viskositas dan kekuatan gel akan menurun. Hal ini disebabkan rantai polipeptida hasil hidrolisis mengalami degradasi melalui hidrolisis lanjutan akibat adanya sisa ion $\mathrm{H}^{+}$, efeknya adalah rantai polpeptida pembentuk struktur tiga dimensi menjadi semakin pendek sehingga kekuatan gel semakin menurun.

Dari hasil analisis didapat kekuatan gel gelatin paling tinggi diperoleh oleh perlakuan $\mathrm{a}_{3} \mathrm{~b}_{2}$ (waktu ekstraksi 6 jam ; asam asetat 3\%).

\section{Viskositas Gelatin}

\begin{tabular}{|c|c|c|c|c|c|c|}
\hline \multirow[b]{2}{*}{ Waktu Ekstraksi } & \multicolumn{6}{|c|}{ Jenis Asam } \\
\hline & \multicolumn{2}{|c|}{$\begin{array}{c}\mathrm{b}_{1} \text { (Asam Klorida } \\
4 \%)\end{array}$} & \multicolumn{2}{|c|}{$\begin{array}{c}\mathrm{b}_{2} \text { (Asam Asetat } \\
3 \% \text { ) }\end{array}$} & \multicolumn{2}{|c|}{$\begin{array}{c}\mathrm{b}_{3} \text { (Asam Sitra } \\
6 \%)\end{array}$} \\
\hline \multirow{2}{*}{$a_{1}(4 \mathrm{jam})$} & 4,90 & A & 4,67 & A & 5,10 & A \\
\hline & $\mathrm{b}$ & & a & & c & \\
\hline \multirow{2}{*}{$a_{2}(5$ jam $)$} & 5,30 & B & 5,47 & B & 5,33 & B \\
\hline & a & & c & & $\mathrm{b}$ & \\
\hline \multirow{2}{*}{$a_{3}(6$ jam $)$} & 5,60 & C & 5,83 & C & 5,40 & B \\
\hline & $\mathrm{b}$ & & c & & a & \\
\hline
\end{tabular}

Keterangan: Huruf besar dibaca vertical dan huruf kecil dibaca horizontal.

Dari tabel diatas dapat dilihat pada perlakuan jenis asam b $b_{1}$ (Asam Klorida 4\%) semakin lama waktu ekstraksi semakin tinggi viskositas gelatinnya begitupula pada perlakukan jenis asam $\mathrm{b}_{2}$ (Asam Asetat $3 \%$ ), tetapi pada perlakuan jenis asam $b_{3}$ (Asam Sitrat $6 \%$ ) waktu ekstraksi a 2 (5 jam) dan a 3 (6 jam) yang paling tinggi viskositas gelatinnya. Hal ini disebabkan karena peningkatkan nilai viskositas dapat terjadi apabila waktu ekstraksi semakin lama mampu memecah ikatan peptida pada ikatan yang tepat dengan 
menghasilkan molekul yang lebih panjang (Said, M. Irfan, dkk, 2011).

Dari tabel diatas dapat dilihat pula perlakuan jenis asam memiliki perbedaan yang nyata dimana ketiga jenis asam berbeda nyata. Pada perlakuan waktu ekstraksi $a_{1}$ (4 jam) jenis asam $b_{3}$ (Asam Sitrat 6\%) memiliki viskositas gelatin yang paling tinggi, tetapi pada perlakuan $\mathrm{a}_{2}(5 \mathrm{jam})$ dan $\mathrm{a}_{3}(6 \mathrm{jam})$ jenis asam $\mathrm{b}_{2}$ (Asam Asetat 3\%) yang memiliki viskositas gelatin paling tinggi. Hal ini disebabkan karena konsentrasi larutan asam yang berbeda berpengaruh terhadap bobot molekul yang dihasilkan. Viskositas berhubungan dengan bobot molekul rata-rata gelatin, bobot molekul gelatin berhubungan langsung dengan panjang rantai asam aminonya. Berarti semakin panjang rantai asam amino maka nilai viskositas akan semakin tinggi (Ward dan Courts, 1977).

Dari hasil analisis didapat viskositas gelatin paling tinggi diperoleh oleh perlakuan $\mathrm{a}_{3} \mathrm{~b}_{2}$ (waktu ekstraksi 6 jam ; asam asetat 3\%), yang berarti viskositas gelatin berbanding lurus dengan kekuatan gel gelatin.

\section{Rendemen Gelatin}

\begin{tabular}{|c|c|c|c|c|c|c|}
\hline \multirow[b]{2}{*}{ Waktu Ekstraksi } & \multicolumn{6}{|c|}{ Jenis Asam } \\
\hline & \multicolumn{2}{|c|}{$\begin{array}{c}\mathrm{b}_{1} \text { (Asam Klorida } \\
4 \%)\end{array}$} & \multicolumn{2}{|c|}{$\begin{array}{c}\mathrm{b}_{2} \text { (Asam Asetat } \\
3 \%)\end{array}$} & \multicolumn{2}{|c|}{$\begin{array}{c}\mathrm{b}_{3} \text { (Asam Sitra } \\
6 \% \text { ) }\end{array}$} \\
\hline \multirow{2}{*}{$a_{1}(4$ jam $)$} & 16,83 & A & 15,40 & $\mathrm{~A}$ & 16,64 & $\mathrm{~A}$ \\
\hline & c & & $a$ & & b & \\
\hline \multirow{2}{*}{$a_{2}(5$ jam $)$} & 17,98 & B & 16,25 & B & 17,77 & B \\
\hline & c & & a & & $\mathrm{b}$ & \\
\hline \multirow{2}{*}{$a_{3}(6 \mathrm{jam})$} & 18,78 & $\mathrm{C}$ & 16,94 & $\mathrm{C}$ & 18,64 & $\mathrm{C}$ \\
\hline & b & & a & & b & \\
\hline
\end{tabular}

Keterangan: Huruf besar dibaca vertical dan huruf kecil dibaca horizontal.

Dari tabel diatas dapat dilihat pada perlakuan jenis asam $b_{1}$ (Asam Klorida 4\%) semakin lama waktu ekstraksi semakin tinggi rendemen gelatinnya begitupula pada perlakukan jenis asam $b_{2}$ (Asam Asetat $3 \%$ ) dan $b_{3}$ (Asam Sitrat 6\%). Hal ini disebabkan karena semakin lama waktu ekstraksi menyebabkan kolagen terurai lebih banyak menjadi gelatin. Peningkatan lama pemasakan (ekstraksi) atau pemanasan dalam air akan meningkatkan kelarutan kolagen sehingga rendemen gelatin akan meningkat (Lehninger, 1990).

Dari tabel diatas dapat dilihat pula pada perlakuan waktu ekstraksi $a_{1} \quad$ (4 jam) dan $\mathrm{a}_{2}(5 \mathrm{jam})$ jenis asam $\mathrm{b}_{1}$ (Asam Klorida 4\%) memiliki rendemen gelatin yang paling tinggi, tetapi pada perlakuan a $(6$ jam) jenis asam $b_{1}$ (Asam Klorida 4\%) dan $b_{3}$ (Asam Sitrat 6\%) yang memiliki rendemen gelatin paling tinggi. Hal ini disebabkan karena jumlah nilai rendemen dipengaruhi oleh jenis asam yang digunakan dalam perendaman. Semakin tinggi konsentrasi larutan asam yang digunakan akan menyebabkan larutan perendaman semakin asam sehingga ion $\mathrm{H}^{+}$yang menghidrolisis kolagen dari rantai triple helix menjadi rantai tunggal semakin banyak. Selain itu dapat dilihat dari jenis asam yang digunakan, dimana asam kuat akan menghidrolisis lebih banyak kolagen menjadi gelatin (Astawan, 2003).
Dari hasil analisis didapat jumlah rendemen gel gelatin paling tinggi diperoleh oleh perlakuan $a_{3} b_{1}$ (waktu ekstraksi 6 jam ; asam klorida 4\%). Rendemen yang cukup tinggi pada perlakuan $\mathrm{a}_{3} \mathrm{~b}_{1}$ tersebut diakibatkan oleh proses hidrolisis kolagen menjadi gelatin pada perlakuan tersebut berlangsung cukup baik.

\section{Respon Kimia \\ Derajat Keasamn (pH) Gelatin}

\begin{tabular}{|c|c|c|c|c|c|c|}
\hline \multirow[b]{2}{*}{ Waktu Ekstraksi } & \multicolumn{6}{|c|}{ Jenis Asam } \\
\hline & \multicolumn{2}{|c|}{$\begin{array}{c}\text { b }_{1} \text { (Asam Klorida } \\
4 \% \text { ) }\end{array}$} & \multicolumn{2}{|c|}{$\begin{array}{c}\mathrm{b}_{2} \text { (Asam Asetat } \\
3 \% \text { ) }\end{array}$} & \multicolumn{2}{|c|}{$\begin{array}{c}b_{3} \text { (Asam Sitrat } \\
6 \% \text { ) }\end{array}$} \\
\hline \multirow{2}{*}{$a_{1}(4$ jam $)$} & 5,50 & A & 5,70 & A & 5,83 & A \\
\hline & a & & $\mathrm{b}$ & & $\mathrm{b}$ & \\
\hline \multirow{2}{*}{$a_{2}(5 \mathrm{jam})$} & 5,80 & B & 5,87 & A & 6,10 & B \\
\hline & a & & $\mathrm{a}$ & & $\mathrm{b}$ & \\
\hline \multirow{2}{*}{$a_{3}(6 \mathrm{jam})$} & 5,80 & B & 6,10 & B & 6,47 & $\mathrm{C}$ \\
\hline & a & & b & & c & \\
\hline
\end{tabular}

Keterangan: Huruf besar dibaca vertical dan huruf kecil dibaca horizontal.

Dari tabel diatas dapat dilihat pada jenis asam $b_{1}$ (Asam Klorida 4\%) perlakuan $\mathrm{a}_{2}$ (5 jam) dan $\mathrm{a}_{3}$ (6 jam) memiliki $\mathrm{pH}$ gelatin yang paling tinggi, tetapi pada perlakuan jenis asam $b_{2}$ (Asam Asetat 3\%) dan $b_{3}$ (Asam Sitrat 6\%) perlakuan $\mathrm{a}_{3}(6 \mathrm{jam})$ yang memiliki $\mathrm{pH}$ gelatin paling tinggi. Hal ini disebabkan karena pada saat proses ekstraksi jaringan fibril pada kolagen menjadi jenuh karena adanya reaksi asam, dimana semakin lama waktu ekstraksi $\mathrm{pH}$ akan melewati titik isoelektrik dari komponen-komponen protein nonkolagen (Fatimah, 2006). Titik isoelektrik adalah titik di mana asam amino penyusun protein non-kolagen menjadi dipolar dan memiliki muatan nol sehingga $\mathrm{pH}$ yang rendah akan meningkat (Hart, 2003).

Dari tabel diatas dapat dilihat pula pada perlakuan waktu ekstraksi $a_{1} \quad$ (4 jam) jenis asam $b_{2}$ (Asam Asetat 3\%) dan $\mathrm{b}_{3}$ (Asam Sitrat 6\%) memiliki pH gelatin yang paling tinggi, tetapi pada perlakuan $\mathrm{a}_{2}(5$ jam) dan $\mathrm{a}_{3}(6 \mathrm{jam})$ jenis asam $\mathrm{b}_{3}$ (Asam Sitrat 6\%) yang memiliki rendemen gelatin paling tinggi. Hal ini disebabkan karena nilai pH gelatin disebabkan oleh jenis asam yang digunakan ketika proses demineralisasi diduga masih terbawa ketika dilakukan proses ekstraksi, sehingga mempengaruhi tingkat keasamn gelatin yang dihasilkan. Hal ini dikarenakan jenis asam yang digunakan memiliki konsentrasi yang berbedabeda maka kepekatan asam dan juga asam yang terikat pada ossein akan berbeda-beda. Pada penelitian jenis asam yang digunakan berpengaruh pada $\mathrm{pH}$ gelatin yang dihasilkan (Hinterwaldner, 1977).

Dari hasil analisis didapat $\mathrm{pH}$ gelatin paling tinggi diperoleh oleh perlakuan $a_{3} b_{3}$ (waktu ekstraksi 6 jam ; asam sitrat $6 \%$ ). Nilai $\mathrm{pH}$ gelatin berbanding terbalik dengan kekuatan gel gelatin dan viskositas gelatin.

\section{Kadar Protein Gelatin}

Dari tabel dapat dilihat pada perlakuan jenis asam $\mathrm{b}_{1}$ (Asam Klorida 4\%) semakin lama waktu ekstraksi semakin tinggi kekuatan gel gelatinnya begitupula pada perlakukan jenis asam $b_{2}$ (Asam Asetat 3\%), tetapi pada perlakuan jenis asam $b_{3}$ (Asam Sitrat 6\%) perlakuan $a_{2}$ 
(5 jam) dan a3 (6 jam) memiliki kadar protein gelatin yang paling tinggi. Hal ini disebabkan karena semakin lama proses ekstraksi jumlah kolagen yang terbebas dan dapat dikonversi menjadi gelatin semakin banyak. Kemungkinan tersebutlah yang membuat kadar protein meningkat seiring dengan waktu ekstraksi yang semakin lama (Ward dan Court, 1977).

\begin{tabular}{|c|c|c|c|c|c|c|}
\hline \multirow[b]{2}{*}{ Waktu Ekstraks } & \multicolumn{6}{|c|}{ Jenis Asam } \\
\hline & \multicolumn{2}{|c|}{$\begin{array}{c}\mathrm{b}_{1} \text { (Asam Klorida } \\
4 \%)\end{array}$} & \multicolumn{2}{|c|}{$\begin{array}{c}\mathrm{b}_{2} \text { (Asam Asetat } \\
3 \% \text { ) }\end{array}$} & \multicolumn{2}{|c|}{$\begin{array}{c}\mathrm{b}_{3} \text { (Asam Sitra } \\
6 \%)\end{array}$} \\
\hline \multirow{2}{*}{$a_{1}(4 \mathrm{jam})$} & 66,79 & $\mathrm{~A}$ & 77,83 & A & 65,19 & A \\
\hline & $\mathrm{b}$ & & c & & $a$ & \\
\hline \multirow{2}{*}{$\mathbf{a}_{2}(5 \mathrm{jam})$} & 71,62 & B & 80,04 & B & 68,26 & B \\
\hline & $\mathrm{b}$ & & c & & a & \\
\hline \multirow{2}{*}{$a_{3}(6$ jam $)$} & 76,04 & C & 83,62 & C & 69,08 & B \\
\hline & $\mathrm{b}$ & & c & & a & \\
\hline
\end{tabular}

Keterangan: Huruf besar dibaca vertical dan huruf kecil dibaca horizontal.

Dari tabel diatas dapat dilihat pula pada perlakuan waktu ekstraksi $a_{1} \quad$ (4 jam), $a_{2}(5$ jam $)$ dan $a_{3}(6$ jam $)$ jenis asam $b_{2}$ (Asam Asetat 3\%) memiliki kadar protein gelatin yang paling tinggi. Hal ini disebabkan karena dengan perbedaan jenis asam yang menyebabkan berat jumlah molekul dari setiap asam bertambah sehingga kerapatan molekulnya berbeda-beda, yang mengakibatkan berat molekul kolagen yang ada dalam tulang menjadi mengembang dan akan pecah pada saat pemanasan, sehingga ikatan kovalen yang menghubungkan asam amino satu dengan yang lainnya terputus, memyebabkan banyaknya asam amino yang terkandung. Semakin tinggi kadar protein maka semakin baik jenis asam yang digunakan karena dapat memecah ikatan polipeptida (Santoso, 2015).

Dari hasil analisis didapat kadar protein gelatin paling tinggi diperoleh oleh perlakuan $\mathrm{a}_{3} \mathrm{~b}_{2}$ (waktu ekstraksi 6 jam ; asam asetat 3\%).

\section{Kadar Abu Gelatin}

\begin{tabular}{|c|c|c|c|c|c|c|}
\hline \multirow[b]{2}{*}{ Waktu Ekstraks } & \multicolumn{6}{|c|}{ Jenis Asam } \\
\hline & \multicolumn{2}{|c|}{$\begin{array}{c}\mathrm{b}_{1} \text { (Asam Klorida } \\
4 \%)\end{array}$} & \multicolumn{2}{|c|}{$\begin{array}{c}\mathrm{b}_{2} \text { (Asam Asetat } \\
3 \%)\end{array}$} & \multicolumn{2}{|c|}{$\begin{array}{c}b_{3} \text { (Asam Sitrat } \\
6 \%)\end{array}$} \\
\hline \multirow{2}{*}{$a_{1}(4 \mathrm{jam})$} & 3,26 & $\mathrm{C}$ & 1.95 & $\mathrm{C}$ & 2,64 & B \\
\hline & c & & a & & b & \\
\hline \multirow{2}{*}{$a_{2}(5 \mathrm{jam})$} & 1,92 & B & 1,88 & B & 1,33 & $\mathrm{~A}$ \\
\hline & b & & b & & a & \\
\hline \multirow{2}{*}{$a_{3}(6$ jam $)$} & 0,96 & $\mathrm{~A}$ & 0,64 & $\mathrm{~A}$ & 1,29 & $\mathrm{~A}$ \\
\hline & $\mathrm{b}$ & & a & & c & \\
\hline
\end{tabular}

Keterangan: Huruf besar dibaca vertical dan huruf kecil dibaca horizontal.

Dari tabel diatas dapat dilihat pada perlakuan jenis asam b (Asam Klorida 4\%) semakin lama waktu ekstraksi semakin rendah kadar abu gelatinnya begitupula pada perlakukan jenis asam $b_{2}$ (Asam Asetat $3 \%$ ), tetapi pada perlakuan jenis asam $b_{3}$ (Asam Sitrat $6 \%)$ perlakuan $\mathrm{a}_{2}(5 \mathrm{jam})$ dan $\mathrm{a}_{3}(6 \mathrm{jam})$ memiliki kadar abu gelatin yang paling rendah. Hal ini disebabkan karena panas yang diterima pada saat proses ekstraksi lebih lama, sehingga mineral yang terkandung didalam tulang pun ikut menurun. Selain proses ekstraksi, proses evaporasi dan pengeringan pada gelatin berpengaruh dari menurunnya kadar abu yang terkandung pada gelatin (Rahayu, 2007).
Dari tabel diatas dapat dilihat pula pada perlakuan waktu ekstraksi $a_{1} \quad$ (4 jam) dan $\mathrm{a}_{3}(6$ jam) jenis asam $\mathrm{b}_{2}$ (Asam Asetat 3\%) memiliki kadar abu gelatin yang paling rendah, tetapi pada perlakuan $\mathrm{a}_{2}(5 \mathrm{jam})$ jenis asam $b_{3}$ (Asam Sitrat 6\%) memiliki kadar abu gelatin yang paling rendah. Hal ini disebabkan karena besar kecilnya kadar abu ditentukan pada saat proses demineralisasi dimana jenis asam yang digunakan akan menghasilkan kadar abu yang berbeda-beda. Semakin banyak kalsium yang larut pada proses demineralisasi, maka kadar abu akan semakin rendah. Pada proses tersebut, asam akan bereaksi dengan kalsium fosfat pada tulang (Rahayu, 2007). Semakin kuat jenis asam yang digunakan nilai kadar abunya semakin tinggi. Hal ini diduga kemampuan asam untuk mengekstrak komponen non kolagen pun semakin tinggi, sehingga nilai kadar abu pun menjadi tinggi. (Menurut Ward dan Court, 1977).. Asam asetat yang digunakan untuk demineralisasi merupakan asam organik dan tidak mengandung mineral sehingga pada saat diabukan akan ikut terbakar.

Dari hasil analisis didapat kadar protein gelatin paling tinggi diperoleh oleh perlakuan $a_{3} b_{2}$ (waktu ekstraksi 6 jam ; asam asetat 3\%).

\section{Kesimpulan}

Dari hasil penelitian pendahuluan tulang ikan yang memiliki kandungan protein paling tinggi adalah pada tulang ikan yang berumur 6 bulan yaitu 24,12\%, sedangkan pada tulang ikan yang berumur 4 bulan yaitu $21,64 \%$ dan 5 bulan yaitu 22,77\%. Sehinnga tulang ikan yang digunakan adalah ikan nila yang berumur 6 bulan.

Waktu ekstraksi (4 jam, 5 jam dan 6 jam) berpengaruh nyata terhadap respon kekuatan gel gelatin, viskositas gelatin, rendemen gelatin, derajat keasaman $(\mathrm{pH})$ gelatin, kadar protein gelatin dan kadar abu gelatin terhadap proses ekstraksi gelatin tulang ikan nila.

Jenis asam (Asam Klorida 4\%, Asam Asetat $3 \%$ dan Asam Sitrat $6 \%$ ) berpengaruh nyata terhadap respon kekuatan gel gelatin, rendemen gelatin, derajat keasaman $(\mathrm{pH})$ gelatin, kadar protein gelatin dan kadar abu gelatin terhadap proses ekstraksi gelatin tulang ikan nila.

Interaksi waktu ekstraksi (4 jam, 5 jam dan 6 jam) dan jenis asam (Asam Klorida 4\%, Asam Asetat $3 \%$ dan Asam Sitrat 6\%) berpengaruh nyata terhadap respon kekuatan gel gelatin, viskositas gelatin, rendemen gelatin, derajat keasaman $(\mathrm{pH})$ gelatin, kadar protein gelatin dan kadar abu gelatin terhadap proses ekstraksi gelatin tulang ikan nila.

Hasil uji banding antara gelatin komersial dan gelatin tulang ikan nila didapatkan hasil yang paling mendekati dengan gelatin komersial adalah perlakuan $\mathrm{a}_{3} \mathrm{~b}_{2}$ (waktu ekstraksi 6 jam ; asam asetat 3\%) dengan hasil analisis yaitu kekuatan gel gelatin 132,93 bloom; viskositas 5,83 cP ; jumlah rendemen 16,94; $\mathrm{pH} 6,10$; kadar protein $83,62 \%$; dan kadar abu $0,64 \%$ 


\section{Daftar Pustaka}

1. Adiningsih, Yuni dan Tatik Purwanti. 2015. Karakteristik Mutu Gelatin Ikan Tenggiri (Scomberomorus commersonii) dengan Perendaman Menggunakan Asam Sitrat dan Asam Sulfat. Samarinda: Balai Riset dan Standarisasi Industri Samarinda.

2. Amiruldin, Musfiq. 2007. Pembuatan dan Analisis Karakteristik Gelatin Dari Tulang Ikan Tuna (Thunnus albacares). Bogor: Institut Pertanian Bogor.

3. Astawan M, Aviana T. 2003. Pengaruh jenis larutan perendaman serta metode pengeringan terhadap sifat fisik, kimia, dan fungsional gelatin dari kulit cucut. Jurnal Teknologi dan Industri Pangan: Vol 14 (1): 7 12.

4. Buwano, Ibnu Dwi. 2004. Kebutuhan Asam Amino Esensial Dalam Ransum Ikan. Yogyakarta: Kanisius.

5. Fatimah, Dewi dan Akyunul Jannah. 2008. Efektivitas Penggunaan Asam Sitrat dalam Pembuatan Gelatin Tulang Ikan Bandeng (Chanos chanos forskal). Malang: Universitas Islam Negeri Maulana Malik Ibrahim.

6. Hadi S. 2005. Karakteristik Fisikokimia Gelatin dari Tulang Ikan Kakap Merah (Lutjanus Sp.) Serta Pemanfaatannya dalam Produk Jelly. Bogor: Institut Pertanian Bogor.

7. Haris, M. Azwar. 2008. Pemanfaatan Limbah Tulang Ikan Nila (Oreochromis niloticus) Sebagai Gelatin dan Pengaruh Lama Penyimpanan Pada Suhu Ruang. Bogor: Institut Pertanian Bogor.

8. Hart, H. 2003. Kimia Organik: Suatu Kuliah Singkat. Jakarta: Erlangga.

9. Hinterwaldner, R. 1977. Technologi of gelatin manufacture, In: Ward AG dan Courts A, editors. The Science And technology of Gelatin. New York: Academic Press.

10. Huda, Wahyu Nurul, dkk. 2013. Kajian Karakteristik Fisik dan Kimia Gelatin Ekstraksi Tulang Kaki Ayam (Gallus galus bankiva) dengan Variasi Lama Perendaman dan Konsentrasi Asam. Surakarta: Universitas Sebelas Maret.

11. Lehninger, A.L. 1990. Dasar-Dasar Biokimia. Jilid I. Jakarta: Erlangga. Terjemahan dari: Fundamental of Biochemistry.

12. Rahayu, Fadjar dan Nurul Hidayati Fithriyah. 2007. Pengaruh Waktu Ekstraksi Terhadap Gelatin Dari Tulang Ikan Nila Merah. Jakarta: Universitas Muhammadiyah Jakarta.

13. Said, M. Irfan, dkk. 2011. Karakteristik Gelatin Kambing yang Diproduksi Melalui Proses Asam dan Basa. Yogyakarta: Universitas Gajah Mada.
14. Santoso, Candra dkk. 2015. Perbedaan Penggunaan Konsentrasi Larutan Asam Sitrat Dalam Pembuatan Gelatin Tulang Rawan Ikan Pari Mondol. Semarang: Universitas Dipenogoro.

15. Stainsby G. 1977. The Gelatin Gel and The SolGel Transformation, In: Ward AG dan Courts A, editors. The Science and Technology of Gelatin. New York: Academic press.

16. Suyanto, S.R. 2002. Nila. Jakarta: Penebar Swadaya.

17. Utama, H. 1997. Gelatin Bikin Heboh. Jurnal Halal LPPOM-MUI No. 18: $\quad 10-12$.

18. Wahyuni, M \& Rosmawati. 2003. Perbaikan Daya Saing Industri Pengolahan Perikanan Melalui Pemanfaatan Limbah Non Ikonomis Ikan Menjadi Gelatin. www.dkp.go.id. (Diakses: 22 September 2017).

19. Ward, AG and Courts A. 1977. The Science and Technology of Gelatin. New York: Academic Press. 